\title{
PENGARUH SUPERVISI DAN SARANA PRASARANA DENGAN KINERJA PERAWAT
}

\author{
Andoko ${ }^{1}$, Intan Putri ${ }^{2}$ \\ ${ }^{1}$ Dosen Program Studi Ilmu Keperawatan Universitas Malahayati \\ Email: andoko2013@gmail.com \\ ${ }^{2}$ Mahasiswa Program Studi IImu Keperawatan Universitas Malahayati \\ Email: intanputriii97@gmail.com
}

\section{ABSTRACT: THE EFFECT OF SUPERVISION AND INFRASTRUCTURE FACILITIES WITH NURSING PERFORMANCE}

Background: The quality of nursing care given by a nurse can be measured by making an evaluation system known as performance assessment. There are three factors influencing performance, they are individual factor, organizational factor and psychological factor. The aspects of organizational factor are supervision and infrastructure.

Purpose: This study scrutinized the effect of supervision and infrastructure towards nurse performance at care wards of A Dadi Tjokrodipo Hospital of Bandar Lampung in 2019.

Methods: This is a quantitative study with cross sectional approach. The population of this study is the whole nurse in charge at A Dadi Tjokrodipo Hospital of Bandar Lampung amounting to 46 people. The respondents are 46 people. The data collection technique was conducted by using questionnaire. The statistical test was done with chi square.

Results: Frequency distribution of respondents stated good supervision as many as 24 respondents $(52.2 \%)$, respondents stated good infrastructure as many as 26 respondents (56.5\%), respondents stated good performance as many as 27 respondents (58.7\%). There is an influence of supervision with nurse performance ( $p$ value 0.041 . OR 4.3). There is the influence of facilities and nurse performance ( $p$ value 0.002. OR 9.8) in the Inpatient Room of RSUD A Dadi Tjokrodipo Bandar Lampung.

Conclusion: There is an influence of supervision and facilities with nurse performance. Suggestions on research to nursing care institutions in hospitals through the field of nursing in collaboration with the hospital management to develop their careers by continuing their education and enhancing nursing experience and motivating Nurse's performance is always good.

Keywords: infrastructure, supervision, nurse performance

\section{INTISARI: PENGARUH SUPERVISI DAN SARANA PRASARANA DENGAN KINERJA PERAWAT}

Pendahuluan: Kualitas pelayanan keperawatan yang diberikan oleh perawat dapat diketahui melalui suatu evaluasi yaitu penilaian kinerja. Terdapat tiga faktor yang mempengaruhi kinerja, yaitu faktor individu, faktor organisasi dan faktor psikologi. Salah satunya faktor organisasi adalah supervisi dan sarana prasarana. 
Tujuan: diketahui pengaruh antara sarana prasarana dan supervisi dengan kinerja perawat di Ruang Rawat Inap RSUD A Dadi Tjokrodipo Bandar Lampung Tahun 2019.

Metode: Jenis penelitian kuantitatif, menggunakan pendekatan cross sectional. Populasi pada penelitian ini adalah seluruh perawat pelaksana di RSUD A Dadi Tjokrodipo Bandar Lampung sejumlah 46 orang. Sampel 46 responden. Tehnik pengumpulan data dilakukan dengan menggunakan kuesioner. Uji statistik yang digunakan adalah uji Chi Square.

Hasil: menunjukkan Distribusi frekuensi responden menyatakan supervisi baik yaitu sebanyak 24 responden $(52,2 \%)$, sarana prasarana baik yaitu sebanyak 26 responden (56,5\%), kinerja baik yaitu sebanyak 27 responden $(58,7 \%)$. Ada pengaruh supervisi dengan kinerja perawat ( $p$ value 0,041. OR 4,3). Ada pengaruh sarana prasarana dengan kinerja perawat ( $p$ value 0,002. OR 9,8).

Kesimpulan: ada pengaruh supervisi dan sarana prasarana dengan kinerja perawat. Saran pada penelitian kepada Institusi pelayanan keperawatan agar terus mengembangkan kariernya dengan melanjutkan pendidikan dan meningkatkan pengalaman tentang keperawatan serta memotivasi agar kinerja perawat tetap selalu baik.

Kata Kunci : Sarana Prasarana, Supervisi, Kinerja Perawat

\section{PENDAHULUAN}

Legalitas dan pengakuan profesi keperawatan menjadi lebih jelas setelah disahkan undang-undang nomor 36 tahun 2014 tentang Keperawatan. Namun permasalahan dan isu-isu keperawatan pun masih timbul di antaranya masalah distribusi dan kompetensi tenaga perawat, beserta masalah kewenangan praktik keperawatan mandiri maupun kolaborasi dan hak-hak serta kewajiban perawat yang dirasakan masih dibatasi (Supriyanto, Hariyanti, \& Lestari, 2014).

Perawat dalam melaksanakan tugasnya menerapkan proses keperawatan sebagai pendekatan sistematis dalam memberikan pelayanan keperawatan, yang meliputi lima langkah dalam lingkup praktek keperawatan berdasarkan perkembangan praktik keperawatan di Indonesia, yaitu pengkajian, diagnosa, perencanaan, implementasi, dan evaluasi. Kemampuan perawat sering disamakan dengan kemampuan dalam membuat keputusan dan kegiatan lainnya yang dapat dilihat dalam sistem dokumentasi (Alimul Azis, 2012).

Kualitas pelayanan keperawatan yang diberikan oleh perawat dapat diketahui melalui suatu evaluasi yaitu penilaian kinerja. Penilaian kinerja dilakukan berdasarkan prinsip dan standar profesi sehingga dapat menggambarkan hasil kegiatan perawat. Penilaian kinerja perawat dapat dinilai dari hasil yang dicapai perawat dalam memberikan asuhan keperawatan, baik melalui pengamatan langsung saat proses pemberian asuhan keperawatan atau melalui dokumentasi asuhan keperawatan. Perilaku perawat pelaksana dapat dinilai melalui prestasi kerja, tanggung jawab, ketaatan, kejujuran, dan kerja sama. Hasil kerja perawat pelaksana dapat dinilai melalui dokumentasi asuhan keperawatan yang telah diberikan kepada pasien dibandingkan dengan standar yang telah ditetapkan (Hasibuan, 2016).

Kemampuan melaksanakan tugas merupakan unsur utama dalam kinerja seseorang. Namun, tugas tidak akan dapat terselesaikan 
dengan baik tanpa didukung oleh suatu kemauan. Jika seseorang telah melaksanakan tugas dengan baik, maka dia akan mendapatkan kepuasan terhadap hasil yang dicapai dan tantangan selama proses pelaksanaan. Kepuasan tersebut dapat tercipta dengan strategi memberikan penghargaan yang dicapai, baik berupa fisik maupun psikis (Nursalam, 2016).

Terdapat tiga faktor yang mempengaruhi kinerja, yaitu faktor individu, faktor organisasi dan faktor psikologi. Salah satunya faktor organisasi adalah supervisi, supervisi adalah pengamatan secara langsung dan berkala oleh atasan tehadap pekerjaan yang dilakukan bawahan, apabila ditemukan masalah segera diberikan bantuan yang bersifat langsung guna mengatasinya (Nursalam 2016).

Salah satu bentuk kegiatan yang dilakukan kepala ruangan yaitu melalui supervisi. Supervisi yang dilakukan kepala ruangan berperan untuk mempertahankan segala kegiatan yang telah dijadwalkan dapat dilaksanakan sesuai standar. Supervisi yang dilakukan diharapkan dapat menjadikan setiap orang fokus mengerjakan tugas mereka masingmasing merupakan suatu kegiatan untuk mengembangkan profesionalisme perawat (Karvinen \& Hyrkas, 2008; Dewi, 2014).

Supervisi merupakan salah satu fungsi dari seorang pemimpin dalam usaha untuk menjaga mutu pelayanan dan keselamatan pasien diarea tugasnya. Diruang rawat kegiatan supervisi dilakukan oleh kepala ruangan. Kepala ruangan sebagai orang yang diberikan tanggung jawab untuk mengelola pelayanan disuatu ruang rawat mempunyai andil yang cukup besar untuk meningkatkan kepatuhan perawat dalam melakukan identifikasi pasien melalui kegiatan motivasi, komunikasi dan bimbingan.
Supervisi sebagai suatu proses yang memacu anggota unit kerja untuk berkontribusi secara positif agar tujuan organisasi tercapai (Ilyas, 2014).

Sarana prasarana kerja yang ada harus dipelihara sesuai dengan standar, prosedur, dan metodenya serta dijaga kesiapgunaannya. Jika sarana prasarana sesuai dengan standar rumah sakit maka kinerja perawat dapat meningkat (Moenir, 2015).

Berdasarkan penelitian diketahui terdapat pengaruh sarana prasarana terhadap kinerja perawat (Zainaro, 2017). Sedangkan hasil penelitian diketahui bahwa ada hubungan yang bermakna antara kepemimpinan dan supervisi dengan kinerja perawat dalam pendokumentasian asuhan keperawatan (Dewi, 2014). Selain itu penelitian juga menunjukkan terdapat hubungan antara gaya kepemimpinan dengan pendokumentasian asuhan keperawatan di instalasi rawat inap $C$ RSUP Prof. Dr. R. D. Kandou Manado dan tingkat hubungan pada level sedang (Paat dkk, 2014).

Rumah Sakit Umum Daerah Dr. A. Dadi Tjokrodipo Bandar Lampung adalah rumah sakit milik Pemerintah Kota Bandar Lampung dengan Tipe $\mathrm{C}$ sebagai rumah sakit rujukan 28 Puskesmas induk dan 56 Puskesmas Pembantu di Wilayah Kota Bandar Lampung.

Hasil wawancara kepada Kepala Ruangan di RSUD A Dadi Tjokrodipo Kota Bandar Lampung diketahui bahwa kegiatan supervisi dilakukan setiap bulan sekali yaitu pada minggu pertama. Dan berdasarkan hasil wawancara kepada 10 perawat pelaksana diketahui bahwa sebanyak 7 orang $(70 \%)$ menyatakan kegiatan supervisi keperawatan sudah diadakan oleh kepala ruangan pada tanggal yang tidak ditetapkan (tidak sesuai jadwal), dan 6 orang (60\%) mengatakan dalam pelaksanaannya 
kepala ruangan belum melaksanakan tugas dan fungsi dengan baik, 6 orang (60\%) menyatakan bahwa kepala ruangan yang melaksanakan supervisi hanya menjelaskan struktur dan prosedur yang akan dilakukan sebagai tindak lanjut supervisi, 7 orang $(70 \%)$ kepala ruangan juga jarang memberikan kesempatan kepada perawat untuk merefleksikan dan mereview asuhan keperawatan dan mendiskusikan kasus-kasus pasien secara mendalam. Sedangkan berdasarkan penilaian kinerja diketahui bahwa terdapat 3 perawat (30\%) yang tidak tepat waktu saat pergantian dinas, 7 perawat $(70 \%)$ tidak menjelaskan fasilitas dan lingkungan ruangan pada pasien maupun keluarga.

Menurut perawat pelaksana kendala yang mereka hadapi disebabkan antara lain karena sarana ruangan yang tidak lengkap yaitu sebanyak 7 orang $(70 \%)$, sebagai contoh alat untuk melakukan perawatan luka amat terbatas sehingga satu alat digunakan untuk beberapa pasien. Terhadap kinerja perawat ditinjau dari aspek kedisiplinan masih banyak perawat yang belum dapat mentaati peraturan yang berlaku dalam institusi rumah sakit, seperti pelanggaran terhadap jadwal kerja sebanyak 6 orang (60\%), datang dan pulang tidak pada waktu yang telah ditentukan 5 orang (50\%).

Berdasarkan latar belakang diatas, maka penulis tertarik untuk melakukan penelitian yang berjudul: "Pengaruh antara sarana prasarana dan supervisi dengan kinerja perawat di Ruang Rawat Inap RSUD A Dadi Tjokrodipo Bandar Lampung Tahun 2019"

\section{METODOLOGI PENELITIAN}

Penelitian ini merupakan jenis penelitian kuantitatif dengan metode survey analitik. Penelitian ini menggunakan pendekatan cross sectional. Populasi dalam penelitian ini adalah seluruh perawat pelaksana di Ruang Rawat Inap RSUD A Dadi Tjokrodipo Bandar Lampung sejumlah 46 orang. Penelitian ini menggunakan teknik total sampling sejumlah 46 orang. Penelitian ini dilakukan di RSUD A Dadi Tjokrodipo Bandar Lampung pada tanggal 10 - 24 Mei 2019. Variabel independen dalam penelitian ini adalah sarana dan prasarana, supervise, variabel dependen dalam penelitian ini adalah kinerja. Dalam penelitian ini cara pengumpulan data didapat melalui kuisioner kepada responden. Untuk variabel kinerja kuesioner terdiri dari 20 pertanyaan, variabel supervisi 20 pertanyaan dan variabel sarana prasarana 20 pertanyan dengan 5 pilihan jawaban, skor 5 jika jawaban sangat baik, Skor 4 Jika jawaban baik, Skor 3 Jika jawaban cukup baik, skor 2 jika jawaban kurang baik dan skor 1 jika jawaban tidak baik. Uji statistik yang digunakan adalah uji Chi Square.

\section{HASIL PENELITIAN DAN PEMBAHASAN}

\section{A. Hasil Penelitian \\ 1. Karakteristik Responden}

Tabel 1. Distribusi Frekuensi Responden Berdasarkan Supervisi

\begin{tabular}{|c|c|c|}
\hline $\begin{array}{l}\text { Karakteristik } \\
\text { Responden }\end{array}$ & Jumlah & $\%$ \\
\hline $\begin{array}{l}\text { Usia: } \\
-\quad \leq 30 \text { Tahun } \\
-\quad>30 \text { Tahun }\end{array}$ & $\begin{array}{l}24 \\
22\end{array}$ & $\begin{array}{l}52.2 \\
47.8\end{array}$ \\
\hline $\begin{array}{l}\text { Pendidikan: } \\
\text { - } \quad \text { DIII } \\
\text { Keperawatan } \\
\text { - } \quad \text { S.Kep } \\
\text { - } \quad \text { Ners + S.Kep }\end{array}$ & $\begin{array}{c}24 \\
5 \\
17\end{array}$ & $\begin{array}{l}52.1 \\
10.9 \\
37.0\end{array}$ \\
\hline $\begin{array}{l}\text { Lama Kerja: } \\
-\quad \leq 5 \text { Tahun } \\
-\quad>5 \text { Tahun }\end{array}$ & $\begin{array}{l}20 \\
26\end{array}$ & $\begin{array}{l}43.5 \\
56.5\end{array}$ \\
\hline Jumlah & 46 & 100,0 \\
\hline
\end{tabular}


Berdasarkan tabel 1. diketahui bahwa lebih dari separuh responden berusia $\leq 30$ tahun yaitu sebanyak 24 responden (52,2\%), dengan pendidikan DIII keperawatan sebanyak 24 responden $(52,1 \%)$, dan lama kerja $>5$ tahun sebanyak 26 responden $(56,5 \%)$.

\section{Analisis Univariat}

Tabel 2.

Distribusi Frekuensi Responden Berdasarkan Supervisi, Sarana Prasarana, dan Kinerja Perawat

\begin{tabular}{ccc}
\hline Supervisi & Jumlah & $\%$ \\
Tidak Baik & 22 & 47.8 \\
Baik & 24 & 52.2 \\
\hline Sarana & & \\
Prasarana & & \\
Tidak Baik & 20 & 43.5 \\
Baik & 26 & 56.5 \\
\hline Kinerja & & \\
Tidak Baik & 19 & 41.3 \\
Baik & 27 & 58.7 \\
Jumlah & 46 & 100,0 \\
\hline
\end{tabular}

Berdasarkan tabel 2 diketahui bahwa lebih dari separuh responden menyatakan supervisi baik yaitu sebanyak 24 responden (52,2\%), sarana prasarana baik yaitu sebanyak 26 responden $(56,5 \%)$, kinerja baik yaitu sebanyak 27 responden $(58,7 \%)$.

3. Analisis Bivariat

a. Pengaruh Supervisi Dengan Kinerja Perawat

Tabel 3.

Pengaruh Supervisi Dengan Kinerja Perawat

\begin{tabular}{|c|c|c|c|c|c|c|c|}
\hline \multirow{3}{*}{ Supervisi } & \multicolumn{4}{|c|}{ Kinerja Perawat } & \multirow{3}{*}{ Total } & \multirow{3}{*}{$\begin{array}{c}P \\
\text { Value }\end{array}$} & \multirow{3}{*}{$\begin{array}{c}\text { OR } \\
\text { (Cl 95\%) }\end{array}$} \\
\hline & \multicolumn{2}{|c|}{ Tidak Baik } & \multicolumn{2}{|c|}{ Baik } & & & \\
\hline & $\mathrm{n}$ & $\%$ & $\mathbf{N}$ & $\%$ & & & \\
\hline Tidak Baik & 13 & 59.1 & 9 & 40.9 & 22 & 0.041 & $4,3(1,2-$ \\
\hline Baik & 6 & 25.0 & 18 & 75.0 & 24 & & $15,2)$ \\
\hline Total & 19 & 41.3 & 27 & 58.7 & 46 & & \\
\hline
\end{tabular}

Hasil penelitian didapatkan bahwa dari 22 responden dengan supervisi tidak baik sebanyak 9 responden $(40,9 \%)$ memiliki kinerja yang baik, sedangkan dari 24 responden dengan supervisi baik, sebanyak 18 responden (75,0\%) memiliki kinerja yang baik. Hasil uji chi square didapatkan nilai $p$ value 0,041 , artinya lebih kecil dibandingkan dengan nilai alpha $(0,041<0,05)$. Dengan demikian dapat disimpulkan secara statistik dengan derajat kepercayaan 95\%, diyakini terdapat pengaruh supervisi dengan kinerja perawat di Ruang Rawat Inap RSUD A Dadi Tjokrodipo Bandar Lampung. Sedangkan hasil uji OR diperoleh nilai 4,3 (Cl 95\% 1,2-15,2), artinya responden dengan supervisi baik berpeluang 4,3 kali lebih besar untuk memiliki kinerja yang baik dibandingkan responden dengan supervisi tidak baik. 


\section{b. Pengaruh Sarana prasarana Dengan Kinerja Perawat}

Tabel 4.

Pengaruh Sarana prasarana Dengan Kinerja Perawat

\begin{tabular}{|c|c|c|c|c|c|c|c|}
\hline \multirow{3}{*}{$\begin{array}{c}\text { Sarana } \\
\text { prasarana }\end{array}$} & \multicolumn{4}{|c|}{ Kinerja Perawat } & \multirow{3}{*}{ Total } & \multirow{3}{*}{$\begin{array}{c}P \\
\text { Value }\end{array}$} & \multirow{3}{*}{$\begin{array}{c}\text { OR } \\
\text { (Cl 95\%) }\end{array}$} \\
\hline & \multicolumn{2}{|c|}{ Tidak Baik } & \multicolumn{2}{|c|}{ Baik } & & & \\
\hline & $n$ & $\%$ & $n$ & $\%$ & & & \\
\hline Tidak Baik & 14 & 70.0 & 6 & 30.0 & 20 & 0.002 & $9,8(2,5-$ \\
\hline Baik & 5 & 19.2 & 21 & 80.8 & 26 & & $38,4)$ \\
\hline Total & 19 & 41.3 & 27 & 58.7 & 46 & & \\
\hline
\end{tabular}

Hasil penelitian didapatkan bahwa dari 20 responden dengan sarana prasarana tidak baik sebanyak 6 responden $(30,0 \%)$ memiliki kinerja yang baik, sedangkan dari 26 responden dengan sarana prasarana baik, sebanyak 21 responden $(80,8 \%)$ memiliki kinerja yang baik. Hasil uji chi square didapatkan nilai $p$ value 0,002, artinya lebih kecil dibandingkan dengan nilai alpha $(0,002<0,05)$. Dengan demikian dapat disimpulkan secara statistik dengan derajat kepercayaan 95\%, diyakini terdapat pengaruh sarana prasarana dengan kinerja perawat di Ruang Rawat Inap RSUD A Dadi Tjokrodipo Bandar Lampung. Sedangkan hasil uji OR diperoleh nilai 9,8 (Cl 95\% 1,2-15,2), artinya responden dengan sarana prasarana baik berpeluang $9,8 \mathrm{kali}$ lebih besar untuk memiliki kinerja yang baik dibandingkan responden dengan sarana prasarana tidak baik.

\section{A. Pembahasan}

\section{Pembahasan Univariat} Supervisi

Hasil penelitian menunjukkan bahwa lebih dari separuh responden menyatakan supervisi baik yaitu sebanyak 24 responden $(52,2 \%)$, sedangkan yang menyatakan supervisi tidak baik sebanyak 22 responden $(47,8 \%)$.

Hasil penelitian ini sejalan dengan teori Warouw, (2009), bahwa Kepala ruang merupakan seorang tenaga perawat profesional yang bertanggung jawab dan berwenang dalam mengelola kegiatan pelayanan keperawatan disuatu ruangan serta dalam menjalankan tugasnya mengacu pada standar yang telah ditetapkan dalam pelaksanaan supervisi keperawatan. Supervisi menurut Nursalam (2016) merupakan suatu bentuk dari kegiatan manajemen keperawatan yang bertujuan pada pemenuhan dan peningkatan pelayanan pada klien dan keluarga yang berfokus pada kebutuhan, keterampilan, dan kemampuan perawat dalam melaksanakan tugas.

Hasil penelitian ini sejalan dengan penelitian Graff, dkk (2012) menyatakan bahwa group kelompok perawat yang di supervisi memiliki tingkat pelayanan keperawatan terhadap pasien lebih baik serta lebih meningkatkan sikap dan keterampilan perawat dalam berinteraksi terhadap pasien. 
Peneliti berpendapat bahwa pelaksanaan supervisi yang kurang dirasakan adalah apabila ada masalah tentang pelaksanaan asuhan keperawatan, kepala ruangan mampu mencari sumber masalah (penyebab), Kepala ruangan memberikan sanksi yang tegas kepada perawat pelaksana yang melakukan kesalahan dalam melaksanakan pekerjaannya (skorsing/pemberhentian sementara, dan lain-lain) dan bila ada informasi terkini/terbaru yang berhubungan dengan pekerjaan perawat pelaksana (misalnya tentang kesehatan, asuhan keperawatan), kepala ruangan selalu menyampaikannya, sedangkan yang dianggap baik adalah Kepala ruangan berusaha untuk bekerja secara gigih, Kepala ruangan menjalin hubungan sosial yang baik dengan perawat pelaksana, Kepala ruangan memberikan kesempatan kepada perawat pelaksana untuk menyampaikan ide-ide yang mendukung kemajuan kualitas pelayanan rumah sakit.

Menurut peneliti masih banyaknya perawat yang merasakan supervisi yang diberikan oleh kepala ruangan kurang disebabkan karena tingkat pendidikan antara kepala ruangan dan perawat pelaksana pada tingkat yang sama yaitu S.Kep + Ners, sehingga kepala ruangan merasa tidak perlu memberikan supervisi dengan rinci, karena dianggap perawat pelaksana memiliki pengetahuan yang sama dengannya.

\section{Sarana Prasarana}

Hasil penelitian menunjukkan bahwa lebih dari separuh responden menyatakan sarana prasarana baik yaitu sebanyak 26 responden (56,5\%), sedangkan yang menyatakan sarana prasarana tidak baik sebanyak 20 responden $(43,5 \%)$.

Hasil penelitian ini sejalan dengan teori Moenir (2015) bahwa dalam suatu masyarakat maju dengan peralatan serba canggih, kegiatan dalam kehidupan manusia semakin tergantung pada adanya peralatan, meskipun hanya sebagian. Menyadari hal itu maka sarana kerja yang ada harus senantiasa dipelihara sesuai dengan standar, prosedur dan metodenya serta dijaga kesiapgunaannya (ready for use), sebab kalau tidak maka gangguan pada sarana kerja dapat mempengaruhi pelaksanaan pekerjaan dan akibatnya dapat menghambat proses pelayanan kepada masyarakat.

Hasil penelitian ini sejalan dengan penelitian Hernika (2016), dengan judul Faktor-Faktor Yang Berhubungan dengan Kinerja Perawat diruang Rawat Inap RSUD Cut Nyak Dhien Meulaboh Kabupaten Aceh Barat Tahun 2015, menunjukkan hasil bahwa mayoritas responden menyatakan faktor fasilitas kerja mendukung(44,1\%)dan minoritas responden menyatakan faktor fasilitas kerja tidak mendukung (55,9\%)berdasarkan jawaban dari 59 responden.

Berdasarkan penelitian diketahui bahwa penilaian 
yang rendah adalah diruangan anda, kenyamanan ruang perawatan, dan tata ruang rawat. Sehingga diharapkan pihak rumah sakit dapat mengkondisikan ruangan perawatan dengan nyaman guna mendukung kinerja perawat. Sedangkan sarana yang dianggap mencukupi adalah tempat ibadah di ruangan, instalasi listrik di ruangan dan kemudahan dalam mengakses alat yang dibutuhkan.

$$
\text { Menurut peneliti }
$$

sarana prasarana kerja yang ada harus dipelihara sesuai dengan standar, prosedur, dan metodenya serta dijaga kesiapgunaannya. Jika sarana prasarana sesuai dengan standar rumah sakit maka kinerja perawat dapat meningkat.

\section{Kinerja}

Hasil penelitian menunjukkan bahwa lebih dari separuh responden menyatakan kinerja baik yaitu sebanyak 27 responden (58,7\%), sedangkan yang menyatakan kinerja tidak baik sebanyak 19 responden (41,3\%).

Hasil penelitian ini sejalan dengan teori bahwa kinerja adalah perbandingan hasil yang dicapai dengan peran serta tenaga kerja persatuan waktu (lazimnya jam). Prestasi kerja atau hasil kerja (output) baik kualitas maupun kuantitas yang dicapai sumber daya manusia persatuan periode waktu dalam melaksanakan kerjanya sesuai dengan tanggung jawab yang diberikannya kepadanya (Mangkunegara,

2015).
Hasibuan (2016), berpendapat bahwa umur individu mempengaruhi kondisi fisik, mental, kemampuan kerja, tanggung jawab, dan cenderung absensi. Sebaliknya, karyawan yang umurnya lebihtua kondisi fisiknya kurang, tetapi bekerja ulet, dan mempunyai tanggung jawab yang lebih besar. Notoatmodjo (2013), menyatakan bahwa orangorang yang memiliki pendidikan yang lebih tinggi akan memiliki pengetahuan yang lebih tinggi pula jika dibandingkan dengan orangorang yang memiliki pendidikan yang rendah dan melalui pendidikan seseorang dapat meningkatkan kematangan intelektual sehingga dapat membuat keputusan dalam bertindak. Dari hasil penelitian yang ada, peneliti berpendapat bahwa salah satu faktor yang dapat meningkatkan produktifitas atau kinerja perawat adalah pendidikan formal perawat. Pendidikan memberikan pengetahuan bukan saja yang langsung dengan pelaksanaan tugas, tetapi juga landasan untuk mengembangkan diri serta kemampuan memanfaatkan semua sarana yang ada di sekitar kita untuk kelancaran tugas. Tenaga keperawatan yang berpendidikan tinggi motivasinya akan lebih baik karena telah memiliki pengetahuan dan wawasan yang lebih luas dibandingkan dengan perawat yang berpendidikan rendah Menurut Nursalam (2016) bahwa semakin banyak masa kerja perawat maka semakin banyak pengalaman perawat tersebut 
dalam memberikan asuhan keperawatan yang sesuai dengan standar atau prosedur tetap yang berlaku.

Hasil penelitian ini sejalan dengan penelitian dari Indrawati (2014) bahwa perawat pelaksana yang berumur Masa $6<32$ tahun mempunyai kinerja kurang $(53,4 \%) \quad$ lebih besar dibandingkan dengan perawat pelaksana umur $\geq 32$ tahun $(33,7 \%)$. Dari hasil penelitian bahwa karakteristik seorang perawat berdasarkan umur sangat berpengaruh terhadap kinerja dalam praktik keperawatan, dimana semakin tua umur perawat makan dalam menerima sebuah pekerjaan akan semakin bertanggung jawab dan berpengalaman. Usia yang semakin meningkat akan meningkat pula kebijaksanaan kemampuan seseorang dalam mengambil keputusan, berpikir rasional, mengendalikan emosi, dan bertoleransi terhadap pandangan orang lain, sehingga berpengaruh terhadap peningkatan kinerjanya.

Penilaian kinerja yang paling rendah terdapat pada pernyataan tentang tindakan perawat dalam melakukan mobilisasi dan membantu BAK/BAB terhadap pasien yang membutuhkan, karena umumnya tindakan tersebut dilakukan secara langsung oleh keluarga pasien, selain itu perawat tidak selalu mengerjakan pekerjaan dengan teliti. Hal ini dikarenakan perawat biasanya mengerjakan lebih dari satu pekerjaan di waktu yang bersamaan. Dan perawat tidak mengikuti pertemuan berkala yang diagendakan kepala ruangan. Karena biasa jadwal tersebut tidak bersamaan dengan jadwal dinas, atau saat perawat libur. Sedangkan penilaian kinerja yang paling baik adalah tindakan perawat dalam melakukan persiapan pasien, tindakan perawat dalam menerima pasien baru dan tindakan perawat melakukan tindakan keperawatan kepada pasien.

Dari hasil penelitian yang didapat, maka peneliti berpendapat pengalaman bekerja pada pekerjaan sejenis perlu mendapatkan pertimbangan dalam penempatan tenaga kerja. Kenyataan menunjukkan makin lama tenaga kerja bekerja, makin banyak pengalaman yang dimiliki tenaga kerja yang bersangkutan. Sebaliknya, makin singkat masa kerja, makin sedikit pengalaman yang diperoleh. Pengalaman bekerja banyak memberikan keahlian dan keterampilan kerja. Sebaliknya, terbatasnya pengalaman kerja mengakibatkan tingkat keahlian dan keterampilan yang dimiliki makin rendah. Pengalaman bekerja merupakan modal utama seseorang untuk terjun dalam bidang tertentu.

\section{Pembahasan Bivariat}

$$
\begin{aligned}
& \text { Pengaruh Supervisi } \\
& \text { Dengan Kinerja Perawat }
\end{aligned}
$$

Hasil uji chi square didapatkan nilai $p$ value 0,041 , artinya lebih kecil dibandingkan dengan nilai alpha $(0,041<0,05)$. Dengan demikian dapat disimpulkan secara statistik dengan derajat 
kepercayaan 95\%, diyakini terdapat pengaruh supervisi dengan kinerja perawat di Ruang Rawat Inap RSUD A Dadi Tjokrodipo Bandar Lampung. Sedangkan hasil uji OR diperoleh nilai 4,3 (Cl 95\% 1,2$15,2)$ artinya responden dengan supervisi baik berpeluang 4,3 kali lebih besar untuk memiliki kinerja yang baik dibandingkan responden dengan supervisi tidak baik.

Hasil penelitian ini sejalan dengan teori bahwa Kepala ruang merupakan manajer pada level pertama dalam manajemen di unit perawatan rawat inap yang memiliki tugas mengontrol kinerja perawat secara langsung (Tappen, 1998 dalam Putra dan Subekti, 2010). Kaitannya dengan pendokumentasian asuhan keperawatan tersebut, kepala ruangan memiliki tugas untuk memberikan pendampingan. Supervisi terhadap anggota ruangannya karena sebagian besar hasil dari audit dokumentasi masih kurang dari nilai 75 (Keliat, 2012).

Menurut Keliat (2012) supervisi adalah proses pengawasan terhadap pelaksanaan kegiatan untuk memastikan apakah kegiatan tersebut berjalan sesuai tujuan organisasi dan standar yang telah ditetapkan. Dengan demikian, Sebagai manajer terdepan yang langsung mengelola asuhan kepada klien, kepala ruangan harus mampu mengelola staf keperawatan maupun sumber daya lainnya melalui supervisi, sehingga staf termotivasi untuk senantiasa meningkatkan kinerjanya dan berkoordinasi dengan tenaga kesehatan lainnya dalam rangka memberikan asuhan keperawatan yang berkualitas kepada pasien.

Hasil penelitian ini sejalan dengan penelitian yang telah dilakukan Wirawan, et al., (2013) menyimpulkan bahwa Terdapat hubungan antara supervise kepala ruang dengan pendokumentasian asuhan keperawatan di Rumah Sakit Umum Daerah Ambarawa. Kemudian, Foury Erawati (2014) hasil penelitiannya diketahui bahwa supervise berpengaruh positif terhadap kinerja pegawai. Kemudian, Putra dan Subekti (2010) menyatakan kesimpulannya bahwa semakin tinggi pelaksanaan fungsi perencanaan yang dilakukan oleh kepala ruangan maka semakin baik pula kinerja ketua tim. Implikasi terhadap keperawatan pada penelitian ini adalah perlu dilakukan peningkatan kemampuan fungsi perencanaan kepala ruangan melalui pelatihan perencanaan strategi dan pengembangan konsep manajerial keperawatan. Hasil penelitian juga menunjukkan terdapat 22 responden dengan supervisi tidak baik sebanyak 9 responden $(40,9 \%)$ memiliki kinerja yang baik. Menurut peneliti hasil tersebut dapat disebabkan karena tingkat pendidikan antara kepala ruangan (supervisor) dengan perawat pelaksana yang sama, sehingga sekalipun tidak mendapatkan supervisi yang baik, mereka dapat melakukan pekerjaan sesuai dengan standar yang berlaku. Selain itu terdapat 6 responden $(25,0 \%)$ dengan supervisi baik 
namun memiliki kinerja tidak baik. Hal ini dapat disebabkan karena terdapat perawat dengan pendidikan DIII keperawatan, sehingga kemampuan perawat dalam memahami informasi yang diberikan tidak sebaik perawat yang memiliki pendidikan SI Keperawatan / Ners. Peran pendidikan adalah memberikan bimbingan, pengajaran, dan pelatihan. Disatu pihak, organisasi yang mempekerjakan tenaga kerja yang menjalankan roda organisasi mulai dari kelompok manajerial sampai dengan petugas yang melaksanakan kegiatan yang bersifat teknis operasional, mengaharap dan bahkan menuntut kinerja dan produktifitas yang tinggi. Sedangkan dilain pihak, pendidikan formal yang telah ditempuh merupakan modal yang penting, karena dapat menguasai suatu disiplin ilmu. Walaupun disiplin ilmu tersebut masih perlu diadaptasikan kepada persyaratan dan tuntunan khusus yang ditentukan oleh organisasi tertentu.

\section{Pengaruh Sarana prasarana Dengan Kinerja Perawat}

Hasil uji chi square didapatkan nilai $p$ value 0,002 , artinya lebih kecil dibandingkan dengan nilai alpha $(0,002<0,05)$. Dengan demikian dapat disimpulkan secara statistik dengan derajat kepercayaan 95\%, diyakini terdapat pengaruh sarana prasarana dengan kinerja perawat di Ruang Rawat Inap RSUD A Dadi Tjokrodipo Bandar Lampung. Sedangkan hasil uji OR diperoleh nilai 9,8
(Cl 95\% 1,2-15,2), artinya responden dengan sarana prasarana baik berpeluang 9,8 kali lebih besar untuk memiliki kinerja yang baik dibandingkan responden dengan sarana prasarana tidak baik.

Hasil penelitian ini sesuai dengan teori yang dikemukan oleh Moenir (2016) bahwa sarana prasarana kerja yang ada harus dipelihara sesuai dengan standar, prosedur, dan metodenya serta dijaga kesiapgunaannya. Jika sarana prasarana sesuai dengan standar rumah sakit maka kinerja perawat dapat meningkat.

Berdasarkan hasil penelitian didapatkan bahwa sarana prasarana yang baik akan meningkatkan kepuasan kerja perawat. Semakin baik sarana prasarana yang dimiliki oleh rumah sakit maka akan semakin puas perawat dalam melakukan pekerjaannya. Hal ini sesuai dengan teori yang dikemukan oleh Asmuji (2012; Zainaro, 2016) menyatakan bahwa jika individu dalam bekerja tidak mendapatkan kebutuhan yang cukup, individu akan merasa tidak puas. Kenyataan ini dapat membuat individu keluar dari pekerjaannya. Sebaliknya, jika individu terpenuhi kebutuhannya, dia merasa puas dengan pekerjaannya.

Hasil penelitian ini sejalan dengan penelitian Zainaro (2016), dengan judul Pengaruh Sarana Prasarana, pendidikan dan masa kerja terhadap kepuasan kerja dan kinerja perawat di Ruang Rawat Inap RSUD A. Dadi Tjokrodipo Bandar Lampung, menunjukkan hasil bahwa sarana prasarana memiliki 
pengaruh yang signifikan terhadap kepuasan kerja dan kinerja perawat sebesar 0,290 dengan taraf signifikasi sebesar $0,014<$ nilai $p$ value 0,05 .

Dalam penelitian ini terdapat 20 responden dengan sarana prasarana tidak baik sebanyak 6 responden $(30,0 \%)$ memiliki kinerja yang baik, menurut peneliti hal ini dapat disebabkan karena tingkat kesadaran perawat yang tinggi untuk melaksanakan pekerjaan sesuai dengan standar yang ada, sehingga sekalipun sarana prasarana tidak mendukung namun pekerjaan yang dihasilkan baik, dengan memanfaatkan sarana prasarana yang tersedia, selain itu terdapat 5 responden $(19,2 \%)$ dengan sarana prasarana baik namun memiliki kinerja tidak baik, hal ini karena kurangnya kesadaran perawat untuk melakukan pekerjaan sesuai dengan standar sekalipun telah didukung oleh sarana prasarana yang menunjang.

\section{Keterbatasan Penelitian}

Dalam melakukan penelitian ini, terdapat beberapa keterbatasan yang mungkin dapat mempengaruhi hasil penelitian ini, diantaranya adalah sebagai berikut:

1. Penelitian ini menggunakan penelitian kuantitatif dengan pendekatan cross sectional, sehingga masih perlu dilakukan penelitian secara kualitatif agar diperoleh hasil penelitian yang lebih mendalam mengenai kinerja perawat.

2. Penelitian ini dilakukan di seluruh rawat inap yang berbeda-beda tempat ruangan sehingga dalam pengisian kuesioner peneliti tidak dapat mengawasi secara penuh pengisian kuesioner yang diisi responden

\section{KESIMPULAN DAN SARAN}

\section{Kesimpulan}

1. Distribusi frekuensi responden menyatakan supervisi baik yaitu sebanyak 24 responden (52,2\%), sedangkan yang menyatakan supervisi tidak baik sebanyak 22 responden $(47,8 \%)$.

2. Distribusi frekuensi responden menyatakan sarana prasarana baik yaitu sebanyak 26 responden (56,5\%), sedangkan yang menyatakan sarana prasarana tidak baik sebanyak 20 responden $(43,5 \%)$.

3. Distribusi frekuensi responden menyatakan kinerja baik yaitu sebanyak 27 responden $(58,7 \%)$, sedangkan yang menyatakan kinerja tidak baik sebanyak 19 responden $(41,3 \%)$.

4. Ada pengaruh supervisi dengan kinerja perawat di Ruang Rawat Inap RSUD A Dadi Tjokrodipo Bandar Lampung ( $p$ value 0,041. OR 4,3).

5. Ada pengaruh sarana prasarana dengan kinerja perawat di Ruang Rawat Inap RSUD A Dadi Tjokrodipo Bandar Lampung ( $\mathrm{p}$ value 0,002. OR 9,8).

\section{Saran}

1. Bagi Rumah Sakit

Diharapkan pihak rumah sakit dapat mengkondisikan ruangan perawatan dengan nyaman guna mendukung kinerja perawat.

Hasil penelitian ini menunjukkan bahwa sarana prasarana merupakan faktor 
yang berhubungan dengan kinerja perawat, oleh karena itu kepada Institusi pelayanan keperawatan di rumah sakit melalui bidang keperawatan bekerja sama dengan pihak manajemen rumah sakit dipandang perlu meningkatkan sarana prasarana di ruangan rawat inap, memberikan dukungan kepada perawat pelaksana agar terus mengembangkan kariernya dengan melanjutkan pendidikan dan meningkatkan pengalaman tentang keperawatan serta memotivasi agar kinerja perawat tetap selalu baik.

2. Bagi Penelitian Keperawatan Untuk mengembangkan penelitian keperawatan maka disarankan bagi calon peneliti selanjutnya untuk dapat melakukan penelitian lanjutan terkait variabel lain yang mempengaruhi kinerja perawat dengan menggunakan sampel yang lebih besar.

\section{DAFTAR PUSTAKA}

Dewi, M., \& Zestin, R. (2014). Hubungan Kepemimpinan Dan Supervisi Dengan Kinerja Perawat Pelaksana Dalam Pendokumentasian Asuhan Keperawatan. Jurnal Manajemen Keperawatan, 2(1), 13-21.

Erawati, F. (2014). Pengaruh Supervisi, Lingkungan Kerja Dan Insentif Terhadap Kinerja Pegawai (Studi Terhadap Account Representative (AR) Pada KPP Madya DKI Jakarta) (Doctoral dissertation, Universitas Terbuka).

Francke, A. L., \& de Graaff, F. M. (2012). The effects of group supervision of nurses: A systematic literature review. International journal of nursing studies, 49(9), 1165-1179.

Hasibuan, M. S. (2016). Manajemen sumber daya manusia. Bumi Aksara.llyas, Y. (2014). Teori, Penilaian dan Penelitian

HERNIKA, N. (2016). FAKTOR-FAKTOR YANG BERHUBUNGAN DENGAN KINERJA PERAWAT DI RUANG RAWAT INAP RSUD CUT NYAK DHIEN MEULABOH KABUPATEN ACEH BARAT TAHUN 2015 (Doctoral dissertation, Universitas Teuku Umar Meulaboh).

Hidayat, A. A. (2011). Metode penelitian kebidanan dan teknik analisis data. Jakarta: salemba medika, 43-44.

Idrawati, B. (2014). Hubungan Budaya Organisasi dengan Kinerja Perawat Pelaksana di Ruang Rawat Inap Rumah Sakit Islam Ibnu Sina Yarsi Padang (Doctoral dissertation, Universitas Andalas).

Kumajas, F. W., Warouw, H., \& Bawotong, J. (2014). Hubungan karakteristik individu dengan kinerja perawat di ruang rawat inap penyakit dalam RSUD Datoe binangkang kabupaten bolaang mongondow. Jurnal Keperawatan, 2(2).

Moenir, A. S. (2015). Manajemen pelayanan umum di Indonesia. Bumi Aksara.Nursalam. (2016). Manajemen Keperawatan: Aplikasi Dalam Praktik Keperawatan Profesional. Jakarta: Salemba Medika. 
Notoatmodjo, S. (2013). Konsep Penelitian Kesehatan. Jakarta: Rineka Cipta.

Nursalam, N. (2007). Manajemen keperawatan: Aplikasi dalam praktek keperawatan profesional. Jakarta: Salemba Medika.

Paat, S. T., Robot, F., \& Lolong, J. (2014). Hubungan Antara Gaya Kepemimpinan Dengan Pendokumentasian Asuhan Keperawatan Di Instalasi Rawat Inap C RSUP Prof. Dr. RD Kandou Manado. Jurnal keperawatan, 2(2)..

Putra, K. R., \& Subekti, I. (2010). Pengaruh Pelaksanaan Fungsi Manajerial Kepala Ruang Dalam Metode Penugasan Tim Terhadap Kinerja Ketua Tim Di RSU Dr Saiful Anwar Malang. Jurnal Keperawatan, 1(2).

SIROLA-KARVINEN, P. I. R. J. O., \& Hyrkaes, K. (2008). Administrative clinical supervision as evaluated by the first-line managers in one health care organization district. Journal of nursing management, 16(5), 588-600.

Sugiharto, A. S., Keliat, B. A., \& Hariyati, T. S. (2012). Manajemen keperawatan aplikasi MPKP di rumah sakit. Jakarta: EGC.

Supriyanto, E., Hariyanti, T., \& Lestari, E. W. (2014). Analisa Faktor-faktor Penyebab Tidak Lengkapnya Laporan Standar Pelayanan Minimal Rumah Sakit di Rumah Sakit Muhammadiyah Ahmad Dahlan Kota Kediri. Jurnal Kedokteran Brawijaya, 28(1), 36-40.
Wirawan, E. A., Novitasari, D., \& Wijayanti, F. (2013). Hubungan Antara Supervisi Kepala Ruang Dengan Pendokumentasian Asuhan Keperawatan Di Rumah Sakit Umum Daerah Ambarawa. Jurnal Manajemen Keperawatan, 1(1).

Zainaro, M. A. (2017). PENGARUH SARANA PRASARANA, PENDIDIKAN DAN MASA KERJA PERAWAT TERHADAP KEPUASAN KERJA DAN KINERJA PERAWAT DI RUANG RAWAT INAP RUMAH SAKIT UMUM DAERAH Dr. A. DADI TJOKRODIPO BANDAR LAMPUNG. HOLISTIK JURNAL KESEHATAN, 11(1), 34-41. 